\title{
ADENOMATOUS POLYPOSIS COLI IN AN ELDERLY FEMALE NIGERIAN
}

\author{
O. B. ALESE and D. O. IRABOR \\ Division of Gastrointestinal Surgery, Department of Surgery, University College Hospital, Ibadan, \\ Nigeria.
}

Corresponding author: Olatunji B. Alese

Conflict of interest: None

\section{SUMMARY}

Colorectal cancer is reported to occur in lower rates in Africans and some of the reasons adduced include a rarity of polyposis coli syndromes. Only two cases of polyposis coli have been documented in Nigeria in the last 15 years. The present case is an elderly lady who had radiologic and colonoscopic evidence of multiple colonic polyps. She had a colonic resection and the histology was reported as multiple polyposis coli, follicular hyperplasia and submucosal fibrosis in the appendix, and reactive hyperplasia in the mesenteric lymph nodes. There was no evidence of malignancy. This is the first case report of polyposis coli in a living elderly patient in Nigeria.

Keywords: Polyposis coli, malignancy, familial adenomatous polyposis, Nigeria.

\section{CASE REPORT}

A 70 year old woman presented with recurrent bloody diarrhoea for four years. She was diabetic and hypertensive, on treatment. Colonoscopy revealed multiple polyps of varying sizes $(5-15 \mathrm{~mm})$ from the rectum to the caecum. The carcinoembryonic antigen level was $3.8 \mu \mathrm{g} / \mathrm{L}$. At surgery an extended right hemicolectomy and ileocolic anastomosis was done.

Histology was reported as follows: "Received $20 \mathrm{~cm}$ length of terminal ileum, as well as $48 \mathrm{~cm}$ of colon and $6 \mathrm{~cm}$ of appendix. The small intestine shows no focal lesion. The colon shows multiple pedunculated and sessile polyps extending from $18 \mathrm{~cm}$ distal to the resection margin although there is marked diffuse thickening of the colon over the polyposis segment. The polyps range in size from $0.3 \mathrm{~cm}$ to $5.5 \mathrm{~cm}$ in widest diameter. The appendix appears grossly normal. Eleven lymph nodes were sampled. Cut section shows tan-coloured appearances. Sections of the colon show mucosa composed of numerous polypoidal growths that are lined by simple columnar epithelial cells and goblet cells. The stalk is composed of fibrovascular tissue. There is mild dysplasia in some of the epithelial cells lining the glands. The resection margins are normal. Sections

\author{
E-mail:aleseob@yahoo.com
}

of the appendix show lymphoid follicular hyperplasia and submucosal fibrosis. Sections of the lymph nodes show reactive hyperplasia. There was no evidence of malignancy." Her postoperative recovery was uneventful.

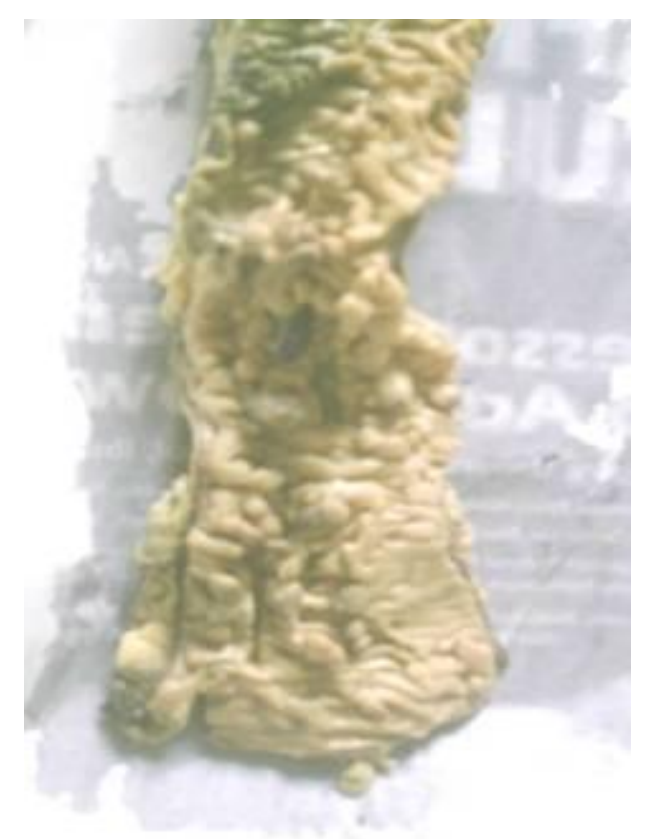

Figure 1 Section of resected bowel

\section{DISCUSSION}

The rarity of polyposis coli syndromes in the Native African has been documented by several authors; indeed, apart from dietary considerations, this is said by many to be the main reason why the incidence of colorectal cancer in Africans is much less than in Europe or the United States of America., ${ }^{1,3}$ The age of our patient raises the possibility of a late penetrant familial adenomatous polyposis (FAP), since the affected patients with classical FAP commonly develop polyposis at the age of 16 years, while the onset of colorectal cancer occurs at 39 years. ${ }^{4,5}$ 
Another variant, the attenuated familial adenomatous polyposis (AFAP) has the onset of polyps at a later age (36 years; with most patients developing cancer by 54 years) and it is associated with fewer polyps (less than 100 polyps) compared to FAP (100-5000 polyps). ${ }^{4,5}$ However, the unavailability of in-vitro protein synthesis assay (or other appropriate genetic testing) makes it difficult to confirm this in the index case. The patient's only child (45year old daughter) is asymptomatic, and does not have colonic polyps on colonoscopy. Efforts to establish an extended family tree are on-going. When a patient is diagnosed with any of the polyposis coli syndromes, one of the most important decisions to be made is the choice of prophylactic surgery. Three options are usually considered; colectomy with ileorectal anastomosis (IRA), proctocolectomy with ileopouch anal anastomosis (IPAA) and proctocolectomy with end ileostomy. ${ }^{6}$ Our choice of the operation of extended right hemicolectomy as against a total colectomy with ileoanal anastomosis was predicated on the premise that the development of short bowel syndrome would be lethal in this patient. A patient of this age (70 years), diabetic and hypertensive would not tolerate the malabsorption and the fluid and electrolyte losses this syndrome will produce. The loss of the ileocecal region or the colon produces a particularly severe short bowel syndrome and the phenomenon of intestinal adaptation will not take place if the ileocecal region has been resected $^{7}$. Thus our surgical option was one which would allow some absorptive segment of colon to remain and also make it easier for sigmoidoscopic surveillance by having only the left colon to screen at 6-monthly intervals. Some authors have also suggested that surgical management of such patients is individualized and decisions should be based on the degree (or severity) of colonic polyposis. $^{8}$

The first documented case of familial polyposis coli in the West African sub-region was that of a 16-year old girl who presented with rectal prolapse, bleeding per rectum, diarrhoea and severe weight loss, of 13 years duration ${ }^{9}$. Rigid sigmoidoscopy and barium enema revealed multiple polyps in all the segments of the colon. Four polyps biopsied at random were reported as malignant. Whilst being prepared for surgery, she deteriorated and died. However, familial polyposis had been reported in a South African Bantu twenty years earlier ${ }^{10}$, and recently in $2002^{3}$.

The second West African case was a 41-year old man who died following presentation with diarrhoea, weight loss, and features of malnutrition ${ }^{11}$. Autopsy showed thousands of polypoid lesions in the colon, with no evidence of malignancy in all the histologic sections examined.
The patient was being treated for abdominal tuberculosis, and the report was made to highlight the need for routine autopsy in the developing world, where there are little or no investigations in confirming uncommon clinical conditions.

In a 20-year review of malignant colorectal neoplasms at University College Hospital, Ibadan, Nigeria ${ }^{12}, 8$ cases of neoplastic polyps were encountered in the rectum, while 2 cases of familial adenomatous polyposis were also observed but not documented or followed up. Of the 34 patients with rectal polyps seen during a five year period at the Central Pathology Laboratory in Zaria, Nigeria, there was no case of polyposis coli. ${ }^{13}$ Neither were any found in 40 Nigerians, who were compared with 89 African Americans (incidence of $11.1 \%$ ) with colorectal polyps, analyzed by age, sex and type of polyp. ${ }^{14}$

The paucity of associated polyps in black African cancer patients has been a subject of much discussion, in view of the well established adenoma-carcinoma sequence. Meanwhile, it has been long established that the various white populations in Africa have similar incidence of intestinal polyps and adenocarcinoma comparable to other white populations in Europe and North America. It would seem that the concurrent rarity of colonic polyps and diverticular disease in the black populations underscores the influence of the "non-western" diet of typical African black communities. ${ }^{1,2,3,15}$ The rapidly changing globalization will confirm or refute this as time goes on. In conclusion, multiple polyposis coli is still a rare condition in West Africa.

\section{REFERENCES}

1. Irabor DO. Colorectal cancer in West Africans: some considerations on its relatively lower incidence compared with Caucasians. Pak J Med Sci 2008;24;331-335.

2. Irabor D, Adedeji OA. Colorectal cancer in Nigeria: 40 years on. A review. Eur J Cancer Care 2009;18;110-115.

3. Grobbelaar JJ, Wilken E, de Ravel TJL, Nicholson DL, Kotze MJ. Familial adenomatous polyposis in 2 black South African families. Clin Genet 2002;61;214-217.

4. Knudsen AL, Bisgaard ML, Bulow S. Attenuated familial adenomatous polyposis (AFAP). A review of the literature. Familial Cancer 2003;2;43-55.

5. Aretz S, Uhlhaas S, Goergens H, Siberg K, Vogel M, Pagenstecher C et al. MUTYH-associated polyposis: 70 of 71 patients with biallelic mutations present with an attenuated or atypical phenotype. Int J Cancer 2006;119;807-814. 
6. Wu JS, Paul P, McGannon EA, Church JM. APC genotype, polyp number and surgical options in FAP. Ann Surg 1998;227;57-62.

7. Irabor DO. The short bowel syndrome. A report of 2 cases. CMEJ 2007;25;147-148.

8. Friedl W, Caspari R, Sengteller M, Uhlhaas S, Lamberti C, Jungck $M$ et al. Can APC mutation analysis contribute to therapeutic decisions in familial adenomatous polyposis (FAP)? Experience from 680 FAP families. Gut 2001; 48;515-521

9. Udofot SU, Ekpo MD, Khalil MI. Familial polyposis coli: an unusual case in West Africa. Cent Afr J Med. 1992 Jan; 38(1):44-48.

10. McQuaide JR, Stewart AW. Familial polyposis of the colon in the Bantu. S Afr Med J. 1972 Sep 2; 46(35):1241-1246.

11. Olasode BJ, Olasode OA. Missed diagnosis adenomatous polyposis coli. Cent Afr J Med. 1997; 43(11):339.
12. Iliyasu Y, Ladipo J. K, Akang E. E. U, Adebamowo C. A, Ajao O. G, Aghadiuno P. U. A twenty-year review of malignant colorectal neoplasms at University College Hospital, Ibadan, Nigeria. Dis Colon Rectum 1996 May 39(5): 536540.

13. Mabogunje OA, Subbuswamy SG, Lawrie JH. Rectal polyps in Zaria, Nigeria. Dis Colon Rectum. 1978 Oct; 21(7):474-479.

14. Williams AO, Chung EB, Agbata A, Jackson MA. Intestinal polyps in American Negroes and Nigerian Africans. $\mathrm{Br} J$ Cancer. 1975 Apr; 31(4):485-491.

15. Segal I, Cooke SA, Hamilton DG, Ou Tim L. Polyps and colorectal cancer in South African Blacks. Gut. 1981 Aug; 22(8): 653-657. 